\title{
JOURNAL
}

OF

\section{PESTICIDE SCIENCE}

\section{Volume 33}

\section{8}

\begin{tabular}{|c|c|c|c|}
\hline \multicolumn{4}{|c|}{ EDITORIAL BOARD } \\
\hline \multirow[b]{2}{*}{ *Miki AKAMATSU } & Editor-in-Chief: & \multicolumn{2}{|l|}{ Hisashi MIYAGAWA } \\
\hline & Tetsu ANDO & Tsutomu ARIE & Tadao AsAmI \\
\hline Makoto FUJIMURA & Takuo FuJISAWA & Takanori HARADA & Andrew HinTON \\
\hline Toshiaki HosHINO & Hideo IsHII & Kazuhito Ітон & Shinzo KaGABU \\
\hline *Arata KATAYAMA & Mitsunori KIRIHATA & Shin KuROGOCHI & Eiichi KuwANO \\
\hline *Kazuhiko MATSUDA & Hiroshi Matsumoto & Toru Мiуамото & $\dagger *$ Hideto MIYOSHI \\
\hline *Kazuhiko МотовА & ${ }^{\dagger *}$ Yoshiaki NAKAGAWA & Kouji NAKAMURA & Akira NAKAYAMA \\
\hline *Takeo OHкOUCHI & Toshiro OHTsuво & Masato OMATSU & Yoshihisa OzoE \\
\hline Isao SAITO & Mitsuru SASAKI & Tsutomu SHIMIZU & Takahiro SHIOTsuKI \\
\hline Toshiji TADA & *Hiroto TAMURA & $\dagger *$ Chihiro TANAKA & Hiroshi TANAKA \\
\hline *Hideki UNEME & Craig E. WHEELOCK & Hiroki YAMAMOTO & Yasuhiro YoGo \\
\hline \multicolumn{4}{|l|}{ Koichi Yoneyama } \\
\hline & * Standing Editors & ${ }^{\dagger}$ Managing Ed & \\
\hline
\end{tabular}

Published by the Pesticide Science Society of Japan

c/o Japan Plant Protection Association

1-43-11 Komagome, Toshima-ku, Tokyo 170-8484, Japan 



\title{
Contents of Volume 33, 2008
}

\author{
No. 1
}

\section{Part I (in English)}

Special Topic: Recent advances in studies on actions of pesticides and bioactive molecules

Toward deeper understanding of bioactive molecules for innovative crop protection

\section{Review}

..Shinkichi TaWATA, Yoshihisa OzoE and Hisashi MiYagawa

Insecticide interactions with $\gamma$-aminobutyric acid and nicotinic receptors: predictive aspects of structural models

\section{Commentaries}

Pharmacophore of neonicotinoid insecticides

Synthesis and biological activity of novel anti-juvenile hormone agents

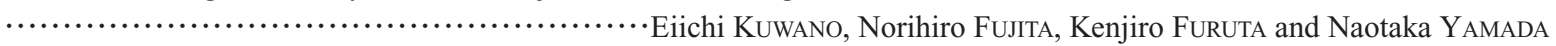

Epoxyalkenyl sex pheromones produced by female moths in highly evolved groups: biosynthesis and its

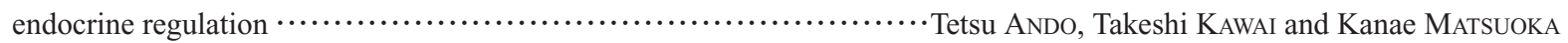

Regulation of bombykol production by tyramine and octopamine in Bombyx mori

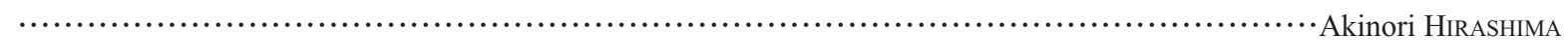

Bombyx mori phenolamine receptors: a comparative molecular biological study.$\cdots \cdots \cdots \cdots \cdots$...... Yoshihisa OzOE and Jia HuANG

Efficacious syntheses of alkylphenol ethoxylates and ethoxycarboxylates with long and single length PEG chain and their application to environmental fate study

Endocrine disruptors that disrupt the transcription mediated by androgen receptor

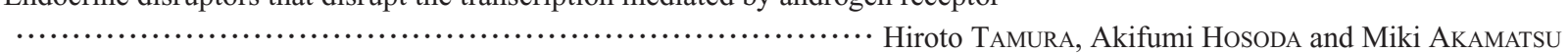

Total utilization of tropical plants Leucaena leucocephala and Alpinia zerumbet

\section{Original Articles}

- Shinkichi TawatA, Masakazu FuKuta, Tran Dang XuAn and Farah DeBA

Insecticidal properties of bistrifluron against sycamore lace bug, Corythucha ciliata (Hemiptera: Tingidae)

Application of commercially available fenitrothion-ELISA kit for soil residue analysis

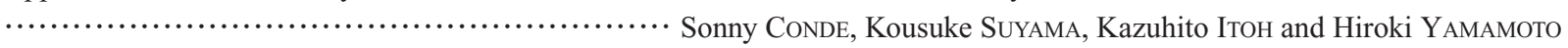

Insecticidal and neuroblocking potencies of variants of the thiazolidine moiety of thiacloprid and quanti-

tative relationship study for the key neonicotinoid pharmacophore

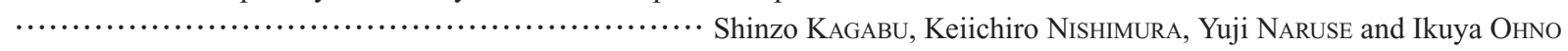

Role of ethylene in abnormal shoot growth induced by high concentration of brassinolide in rice seedlings

Note

- Nguyen Minh Chon, Naoko NishiKawa-KoseKi, Yasutomo TaKeUCHI and Hiroshi ABE

Improvement of ELISA analysis for soil residue analysis by reducing soil matrix effects

\section{Acknowledgments}

Sonny Conde, Kousuke SuYAma and Kazuhito ITOH

Part II (in Japanese)

Original Article (with abstract in English)

Fate and behavior of fenitrothion in the atmosphere after apprication on a paddy fiield

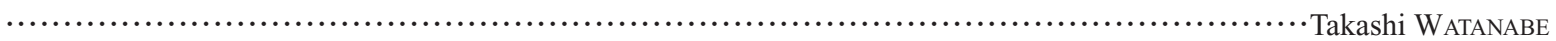




\section{No. 2}

\section{Part I (in English)}

\section{Review}

Biorational insecticides in insect pest management

\section{Short Communication}

Environmental distribution and novel high-throughput screening of APEO-degrading bacteria using matrix-assisted laser desorption/ionization time-of-flight mass spectrometry (MALDI-MS)

\section{Original Articles}

Herbicide sensitivities of mutated enzymes expressed from artificially generated genes of acetolactate synthase

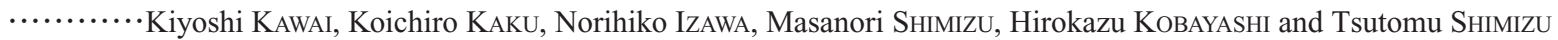

Antagonistic Gluconobacter sp. induces abnormal morphodifferentiation to Fusarium oxysporum f. sp.

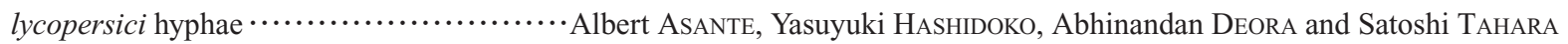

Potentiating and blocking actions of neonicotinoids on the response to acetylcholine of the neuronal

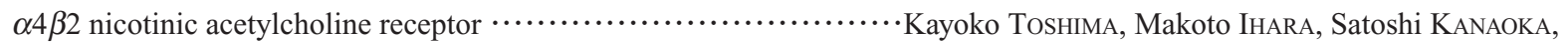
Kiyoshi Tarumoto, Atsushi Yamada, David B. Sattelle and Kazuhiko Matsuda

7,11,13-Hexadecatrienal identified from female moths of the citrus leafminer as a new sex pheromone component: synthesis and field evaluation in Vietnam and Japan ................. Ve Van Vang, MD. Azharul Islam, Nguyen Duc Do, Tran Van HaI, Shinji KoYano, Yoshiki OKaHana, Nobuo OhBAYAshi, Masanobu YAMAmoto and Tetsu ANDO

Excess water storage depth - a water management practice to control simetryn and thiobencarb runoff

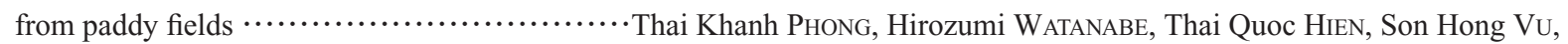
Taku TANAKA, Dang Thi Tuyet Nhung and Takashi MotoBAYASHI

\section{Notes}

Enrichment and isolation of anaerobic microorganisms concerned with reductive degradation of

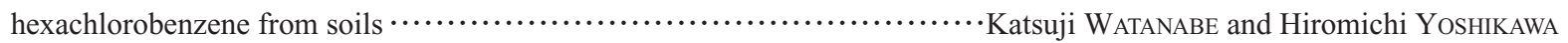

Comparative effects of different families of herbicides on recovery potentials in Lemna sp.

\section{The Society Award Lectures (Abstract)}

Studies on the synthetic development for the discovery of novel heterocyclic agrochemicals

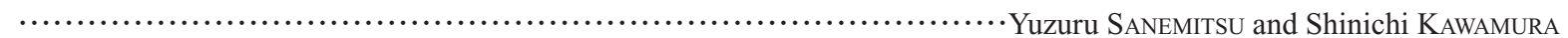

Metofluthrin: novel pyrethroid insecticide and innovative mosquito control agent ........................ Kazuya Ujihara, Noritada Matsuo, Tatsuya Mori, Yoshinori Shono and Tomonori IwASAKI

Part II (in Japanese)

The Society Award Lectures

Note (with Abstract in English)

The effects of plant activators on leaf spot and anthracnose of Chinese cabbage

-Yoshihiro NarusaKa, Mari Narusaka, Tomonori Shiraishi, Kiyoshi Kawai, Norihiko Izawa, Katsunori Hatakeyama, Hiroshi ABE and Masatomo KoBAyashi

\section{Abstracts of Articles in Part I \\ Commentaries}

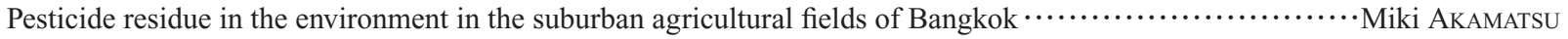

Risk communication: how do we explain the safety of pesticides?

Noriharu UMETSU 
No. 3

\section{Part I (in English) \\ Review}

Unraveling the mystery of spinosad resistance in insects

\section{Original Articles}

Effect of fentrazamide on the growth, morphology and anatomy of Echinochloa crus-galli and Echinochloa oryzicola

Biocontrol activity in a nonpathogenic REMI mutant of Fusarium oxysporum $\mathrm{f}$. sp. conglutinans and characterization

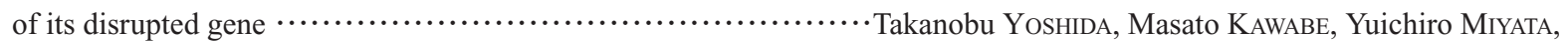

Tohru TERAOKA and Tsutomu ARIE

Lethal dose and horizontal transfer of bistrifluron, a benzoylphenylurea, in workers of the formosan subterranean termite (Isoptera: Rhinotermitidae)

..................................... Shunichi KubotA, Yoshinori Shono, Nobuaki Mito and Kunio TsunOdA

Application of multiple enzyme restriction fragment length polymorphism analysis and microchip electro-

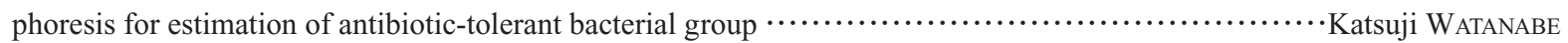

\section{Notes}

Adult vial bioassays of insecticidal toxicity against cotton fleahopper, Pseudatomoscelis seriatus (Hemiptera: Miridae) .............................. J. D. López, Jr., W. C. Hoffmann, M. A. Latheef, B. K. Fritz, D. E. Martin and Y. Lan

Simultaneous biodegradation of chloro- and methylthio-s-triazines using charcoal enriched with a newly developed bacterial consortium

.................Ken-ichi Yamazaki, Kazuhiro TAKagi, Kunihiko FuJII, Akio IwASAKI, Naoki HaradA and Tai UChIMURA

\section{The Society Award Lecture (Abstract)}

Study on the mechanism of insecticidal activity through disruption of intracellular calcium homeostasis

Part II (in Japanese)

The Society Award Lecture

\section{Original Articles (with Abstract in English)}

Drift monitoring of acetamiprid sprayed by an air-blaster on pine trees in Gunma prefecture

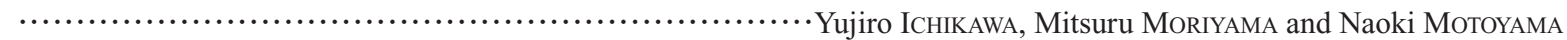

Monitoring and health effect assessment of spray drift following the application of fenitrothion EC by a radio-controlled helicopter over pine trees in Shizuoka prefecture $. . . \cdots \ldots . . . \cdots \cdots$.

\section{Abstracts of Articles in Part I}

\section{Commentaries}

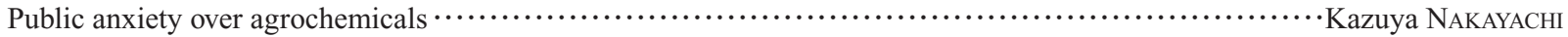

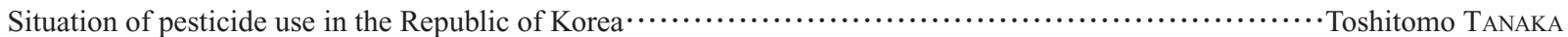

\section{Minireviews: Problems for a long time concerning pesticide use in the field}

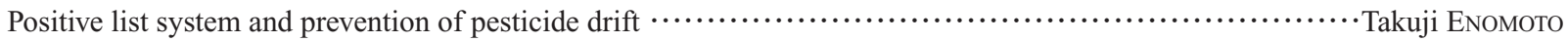

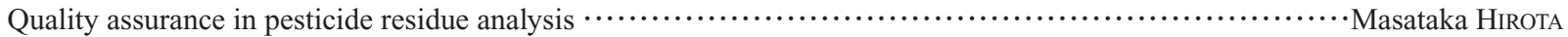

Occurrence and countermeasure of fungicide-resistant pathogens in vegetable field of Osaka prefecture

Occurrence and chemical control of Fusarium head blight on wheat and barley in Shiga prefecture 
No. 4

\section{Part I (in English)}

\section{Review}

Environmental fate and properties of pyriproxyfen

\section{Original Articles}

Insecticide resistance of Aedes aegypti and Culex quinquefasciatus in Thailand

............................ Kanutcharee ThANISPONG, Sunaiyana SATHANTRIPHOP and Theeraphap CHAREONVIRIYAPHAP

2,4-Dioxo-1,3-thiazolidine derivatives as a lead for new fungicides

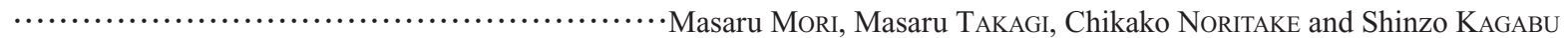

Herbicidal activity of a new paddy bleaching herbicide, benzobicyclon

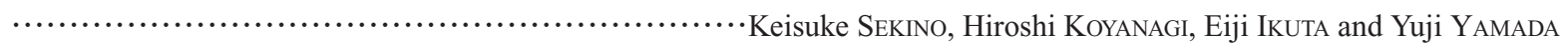

Design of novel carbamate acetylcholinesterase inhibitors based on the multiple binding sites of acetyl-

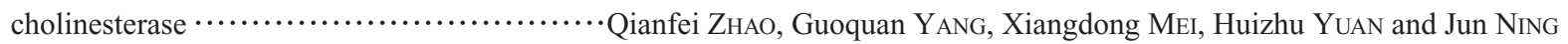

Imazamethabenz hydrolysis on oxide surfaces at several $\mathrm{pH}$

Jin Ho Joo, Charlotte V. EBerLein and Matthew J. Morra

Note

Juvenile hormone activity of optically active ethyl 4-(2-benzylalkyloxy)benzoates inducing precocious metamorphosis

............... Norihiro FuJitA, Kenjiro Furuta, Kiyo Ashibe, Shuhei YoshidA, Naotaka YamadA, Takahiro Shiotsuki,

Makoto KIUCHI and Eiichi KuwANO

Part II (in Japanese)

\section{Original Articles (with Abstract in English)}

Determination of chlorothalonil residues in raw tea and green tea leaves by an enzyme-linked immuno-

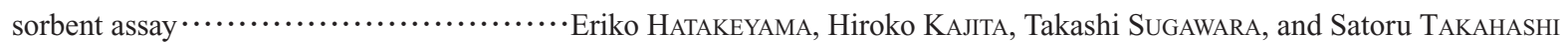

Probabilistic ecological risk assessment of paddy herbicide in Japanese river waters using uncertainty analysis:

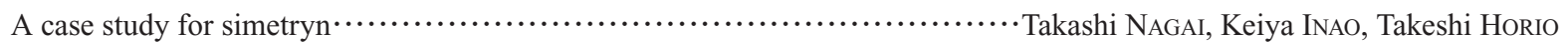

Abstracts of Articles in Part I

\section{Commentary}

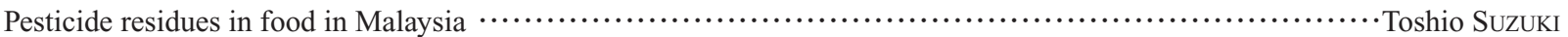

Symposia

\section{Special Topic}

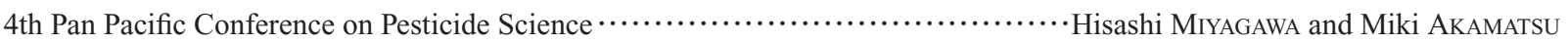

Keyword Index to Volume 33, 2008

Author Index to Volume 33, 2008

Contents of Volume 33, 2008 